\title{
European defence in the melting-pot
}

\section{Decisions due in the next few months could help to stablilize the defence of Western Europe at a less costly level as well as help Mr Gorbachev survive troubles such as those in the Baltic states.}

REASONS why nobody can quite tell the future of European defence hardly need enumeration, but there is an interesting array of them:

- A new president, Mr George Bush, will be installed in the White House on 20 January, and while there is nothing to suggest a break with US policies of the past eight years, it may be significant that Mr Bush himself has been non-committal on the subject. The new administration, in seeking both to cut the federal deficit and to satisfy long-standing conservative complaints, could well insist that Western Europe should bear a larger fraction of the cost of, perhaps even of the responsibility for, its own defence.

- Second, Western Europe is still bemused by the arrival of $\mathrm{Mr}$ Mikhail Gorbachev in power in the Soviet Union, is impressed that there has already been one significant arms control agreement (on weapons of intermediate range), that there is another (on strategic weapons) waiting for Mr Bush's decision about the future of the Strategic Defense Initiative (SDI) and that serious negotiations on yet a third (on conventional forces) are due to begin in the spring. That is why it is taking the West Germans an age to decide whether to accept, early in the 1990s, improved substitutes for the US Lance missiles now sited in West Germany, whose supposed military role is the interdiction of massive conventional forces attacking from the East.

- Eastern Europe, once regarded as indistinguishable from the Soviet Union, no longer seems like that. Taking liberal-sounding Gorbachev perhaps too literally at his word, the Baltic states have been making declarations of what might be called separateness, while Hungary, traditionally in the van of eastern change, seems bent on much more of the same. Even Poland and Czechoslovakia now seem more flexible than a few years or even months ago, while politicians like President Mitterrand of France, no doubt anxious to gain what they can from changing circumstances, have taken to speaking about the restoration of traditional links with the Balkan states.

\section{Back burner?}

So does all that not imply that European defence, meaning the defence of Western Europe, is well on the way to becoming a non-issue, something for the back burner? Sadly, no, because:

- Signs that the Russian Republic may now be less in charge of events on its periphery than a few years ago are not quite the general comfort in the West that they would have been in, say, the 1970s. Instead, they raise in the minds of Western military planners the uneasy prospect that centrifugal tendencies in the Baltic states may precipitate the unthinkable - Mr Mikhail Gorbachev's own collapse. followed by that of perestroika (always a high-risk strategy) and by the return of implacability in the East.

Not for the first time, not all these tendencies are harmoniously in accord. The last and, most often, the unspoken consideration is dominant, but can be argued two ways. One, the most common, is that the possibility that the new liberalism may not be permanent predicates a continuation into the 1990) of the defence arrangements of the 1970), when there was not even an agreement on nuclear weapons of intermediate range. Specifi- cally, this would imply continued reliance on nuclear interdiction of conventional attacks from the East - a view that could only be strengthened by US insistence that Western Europe should learn to stand on its own feet (for nuclear weapons cost only money: strengthening conventional forces entails both monetary and political costs). More generally, this interpretation leads to the conclusion that Western Europe must be armed (to defend itself) to the teeth until Mr Gorbachev can demonstrate that his concept of how the Soviet Union should be run has come to stay.

\section{Opposite interpretation}

That is why more attention should be given to the opposite interpretation of events in the Baltic states and elsewhere in Eastern Europe: that this is eminently the time for striking deals between East and West. The negotiations on conventional forces arranged for next year will evidently be crucial both to East-West relations and the Western European response to continuing pressure from the United States. The snag is that they are bound to take an age and a day. Much, in any case, will hang on the review of policy by the North Atlantic Treaty Organization, also due in the spring. The best outcome would be a declaration that Western Europe and its allies will trade reductions of interdiction weapons (from nuclear artillery to Lance replacements) for progress in the reduction of conventional forces. In retrospect unwisely, the West insisted that these weapons should be exempted from the impending negotiations on conventional weapons.

If that is indeed what happens in the West in the next few months, several stabilizing influences will follow. First. $\mathrm{Mr}$ Gorbachev will have something more to show for his risky willingness to negotiate. Second, it will then seem to his own colleagues a less serious matter if there should persist centrifugal tendencies in peripheral states. (Conversely, progress towards the reduction of interdiction weapons would assist centrifugal forces.) Third, the West German government will be partially relieved of its well-publicized agony about the prospect that nuclear weapons used for interdiction will as often as not fall on West German soil. Fourth, and no less important, these same steps would resolve the potential tension between the United States and Western Europe over their mutual obligations. In short, there is a way in which the apparent circle of contradictions might be squared.

\section{Student debtors rally}

British students have been protesting at the proposed ending of their grants. They have cause. CAPrial cities are incomplete without occasional conflicts between students and the authorities, so that the British government must be commended for having provided the occasion for last Thursday's near-riot in central London. Many years have passed since students and mounted police were previously in conflict during an evening rush-hour. (It is strictly coincidental that Hungarian students were also up in arms last week. 